\title{
Marine cyanophages infecting oceanic and coastal strains of Synechococcus: abundance, morphology, cross-infectivity and growth characteristics
}

\author{
Curtis A. Suttle, Amy M. Chan \\ Marine Science Institute, The University of Texas at Austin, Port Aransas, Texas 78373-1267, USA
}

\begin{abstract}
Eight different phycoerythrin- and phycocyanin-containing strains of Synechococcus spp. and 1 strain of Anacystis marina were screened against 29 natural virus communities taken from 3 locations in south Texas (USA) coastal waters, at different times of the year. In addition, 1 sample was screened from Peconic Bay, New York, USA. Cyanophages were detected in all samples, but the frequency with which they were detected and their abundance depended upon the strain of Synechococcus sp. that was screened. Viruses that infected red Synechococcus spp. strains (DC2, SYN 48) were particularly common and in some instances were in excess of $10^{5} \mathrm{ml}^{-1}$ The abundances of cyanophages were weakly correlated with temperature $\left(r^{2}=0.53\right.$ to 0.70$)$, although they occurred at all of the temperatures $\left(12\right.$ to $30.4^{\circ} \mathrm{C}$ ) and salinities ( 18 to $70 \mathrm{ppt}$ ) that were screened. The 7 cyanophages that were cloned belonged to the same 3 families of viruses that have been observed to infect freshwater cyanobacteria, namely the Siphoviridae (formerly Styloviridae), Myoviridae and Podoviridae. The cyanophage clones varied in host-specificity. For example, 1 clone infected a single Synechococcus sp. strain of 12 that were tested, whereas, another infected 4 of 9 strains tested. Growth characteristics of 1 of the virus clones was determined for a single host (BCCl). Photosynthesis in $\mathrm{BCCl}$ was not affected until near the onset of cell lysis and the virus burst cycle was complete ca $17 \mathrm{~h}$ post-infection. The burst size was approximately 250 infective particles. The high abundance of cyanophages in the natural environment provides further evidence that viruses are probably important regulators of phytoplankton dynamics in marine systems
\end{abstract}

\section{INTRODUCTION}

The existence of cyanophages in freshwater that infect both unicellular and filamentous strains of cyanobacteria has been recognized for some time (e.g. Safferman \& Morris 1967, Stewart \& Daft 1977, Martin $\&$ Benson 1988). Cyanophages have been implicated in the prevention of bloom formation and control of community structure in freshwater systems (Stewart \& Daft 1977, Martin \& Benson 1988). It is surprising, given the importance of cyanobacteria in marine systems as major primary producers ( $\mathrm{Li}$ et al. 1983, Murphy \& Haugen 1985) and nitrogen fixers (Carpenter \& Romans 1991), that there has been little systematic effort to document the occurrence and importance of cyanophages in marine systems. It has only recently been reported that up to $1.5 \%$ of marine Synechococcus spp. contain mature phage (Proctor \& Fuhrman $1990)$ and that infective cyanophages can be readily isolated from seawater (Suttle et al. 1990). These observations suggest that viruses could be a significant cause of mortality for marine Synechococcus spp.

In order to determine the extent to which cyanophages exist in seawater we investigated the occurrence and abundance of viruses which cause lysis of oceanic and coastal strains of Synechococcus spp. and a strain of Anacystis marina. We also investigated cyanophages in terms of host-specificity, adsorption kinetics, time until bursting, burst size and changes in photosynthetic rates following infection, as these parameters are potentially important in dictating the impact of viruses on the cyanobacteria community. In 
addition, we characterized a number of virus clones by transmission electron microscopy (TEM) to ascertain if marine cyanophages are morphologically similar to their freshwater counterparts.

\section{MATERIALS AND METHODS}

Cyanobacteria isolates. Eight marine isolates of Synechococcus spp. and 1 of Anacystis marina (UTEX2380) were screened against natural virus communities. The cyanobacteria were isolated from the coastal waters of Texas, USA (BBC1, BBC2, SNC1, SNC2) or obtained from culture collections at Bigelow Laboratory (DC2, SYN48, 838BG) and The University of Texas at Austin (UTEX 1634, UTEX 2380). DC2 and SYN48 were open ocean isolates; DC2 originated from the North Atlantic $\left(33^{\circ} 45^{\prime} \mathrm{N}, 67^{\circ} 30^{\prime} \mathrm{W}\right)$, and SYN48 was isolated from the tropical Aliantic $108^{\circ} 44^{\prime} \mathrm{N}, 50^{\circ}$ $50^{\prime} \mathrm{W}$ ). The Texas strains SNC1 and SNC2 were isolated from hypersaline Laguna Madre $\left(27^{\circ} 38^{\prime} \mathrm{N}, 97^{\circ}\right.$ $14.5^{\prime} \mathrm{W}$ ), while $\mathrm{BBC} 1$ and $\mathrm{BBC} 2$ were isolated from the small-boat harbor adjacent to the Marine Science Institute $\left(27^{\circ} 50^{\prime} \mathrm{N}, 97^{\circ} 02.2^{\prime} \mathrm{W}\right)$. 838BG was originally isolated from the southern Gulf of Mexico $\left(19^{\circ} 45^{\prime} \mathrm{N}\right.$, $92^{\circ} 25^{\prime} \mathrm{W}$ ). In addition, 4 strains of freshwater Synechococcus spp. (S. leopoliensis, UTEX 625, UTEX 2434; S. cedorum, UTEX 1191; S. elongatus, UTEX 563 ) and 1 strain of Microcystis aeruginosa (UTEX 2385 = NRC-1) were used for host-range studies.

Study sites. The natural virus communities for the screening experiments were concentrated from surface seawater samples collected from 4 locations in Texas coastal waters and 1 station on the eastern end of Long Island, New York, USA (Peconic Bay). In addition, the abundance of cyanophages and cyanobacteria were estimated directly from surface seawater samples taken at 7 stations along a seaward transect originating at $1 \mathrm{~km}$ and ending $41 \mathrm{~km}$ offshore from the Marine Science Institute, on 8 April 1982 (from $27^{\circ} 49^{\prime} \mathrm{N}, \quad 97^{\circ} 01^{\prime} \mathrm{W}$ to $\left.27^{\circ} 35^{\prime} \mathrm{N}, 96^{\circ} 43^{\prime} \mathrm{W}\right)$. The locations of the Marine Science Institute $\left(27^{\circ} 50^{\prime} \mathrm{N}\right.$, $\left.97^{\circ} 02^{\prime} \mathrm{W}\right)$, Laguna Madre $\left(27^{\circ} 30^{\prime} \mathrm{N}, 97^{\circ} 18^{\prime} \mathrm{W}\right)$ and Gulf of Mexico $\left(27^{\circ} 31^{\prime} \mathrm{N}, 96^{\circ} 18^{\prime} \mathrm{W}\right.$ ) sampling stations are illustrated elsewhere (Suttle et al. 1991). Laguna Madre is a hypersaline lagoon (30 to $70 \mathrm{ppt}$ ) which is separated from the Gulf of Mexico by a barrier island. The Gulf of Mexico station was located in oligotrophic waters ( $<0.1 \mu \mathrm{g}$ chlorophyll $\mathrm{a}^{-1}$ ) approximately $70 \mathrm{~km}$ offshore from Port Aransas, Texas. The concentration of cyanophages was determined in 17 seawater samples collected from the Marine Science Institute pier between March 1990 and June 1992. Depending on tide, rainfall, wind and season, the water off of the pier can vary from low salinity $(<20 \mathrm{ppt})$ and estuarine
(3.0 to $10.0 \mu \mathrm{g} \mathrm{chl} \mathrm{a}^{-1}$ ) to high salinity (37 ppt) and oligotrophic $\left(0.1\right.$ to $1.0 \mu \mathrm{g}$ chl a $\left.\mathrm{l}^{-1}\right)$. The Brownsville Channel is located $174 \mathrm{~km}$ south of Port Aransas and is a major pass between Lower Laguna Madre and the Gulf of Mexico. The samples at this location were collected during a dinoflagellate bloom. Peconic Bay is a small, vertically well-mixed estuary with salinities varying between ca 23.5 and 29.5 ppt (Bruno et al. 1980).

Isolation of virus communities and cyanophage distribution. The 30 natural virus communities that were screened for the presence of cyanophages were concentrated from seawater using ultrafiltration as previously described (Suttle et al. 1991). Briefly, 20 to 100 l of seawater were gently filtered through $142 \mathrm{~mm}$ diameter glass-fiber (MFS GC50, $1.2 \mu \mathrm{m}$ nominal poresize) and 0.22 or $0.45 \mu \mathrm{m}$ pore-size low-protein-binding Durapore membrane filters (Millipore) to remove zooplankton, phytoplankton and most bacteria. Subsequently, the viruses in the filtrate were concentrated up to 1100 times using a 30000 MW cutoff spiralwound ultrafiltration cartridge (Amicon S1Y30). Virus concentrates were stored in the dark at $4{ }^{\circ} \mathrm{C}$ until use.

Aliquots from the virus communities were added to exponentially-growing cultures of the cyanobacteria, The cyanobacteria were grown under continuous irradiance $\left(40\right.$ to $50 \mu \mathrm{mol}$ quanta $\mathrm{m}^{-2} \mathrm{~s}^{-1}$ ) at $25^{\circ} \mathrm{C}$ in artificial seawater (ESAW, Harrison et al. 1980) in $13 \times 100$ or $25 \times 150 \mathrm{~mm}$ borosilicate glass tubes with polypropylene screw caps. The amount of concentrate added to each potential host was chosen to be equivalent to the number of viruses that would be in $500 \mathrm{ml}$ of seawater, assuming that the viruses were concentrated with $100 \%$ efficiency. The in vivo chlorophyll fluorescence of these cultures was monitored daily for 7 to $10 \mathrm{~d}$ to look for signs of lysis, which was taken to be evidence of the presence of a viral pathogen. In cultures which lysed, the presence of a viral pathogen was confirmed by propagating $50 \mu \mathrm{l}$ of $0.2 \mu \mathrm{m}$-filtered lysate to replicate tubes of exponentially growing cultures. For tubes that did not lyse, the presence or absence of a pathogen was tested by adding $500 \mu \mathrm{l}$ of unfiltered culture to replicate tubes of exponentially growing cells. On occasion, when the initial viral titer was low, viral pathogens were detected by this subsequent amplification step. For samples in which lytic viruses were detected, the concentration of cyanophages was estimated as outlined below.

Estimation of cyanophage and cyanobacteria concentrations. The concentrations of cyanophages infecting particular hosts were estimated by adding aliquots of exponentially-growing cyanobacteria into each well of a 96-well microtiter plate, followed by one of several dilutions of the sample to be titered. A similar protocol has been used to estimate cyanophage concentrations in waters off the northeast coast of the U.S. 
(J. B. Waterbury pers. comm.). The concentration of viruses was determined directly from natural seawater samples (offshore transect) or in natural virus communities that had been concentrated from seawater by ultrafiltration, as outlined above. Each dilution was replicated 8 times and each assay was duplicated for a total of 16 replicates at each dilution. Controls received no virus addition. The plates were incubated under continuous irradiance ( 10 to $15 \mu \mathrm{mol}$ quanta $\mathrm{m}^{-2} \mathrm{~s}^{-1}$ ) at $25^{\circ} \mathrm{C}$ and the wells monitored daily for 7 to $10 \mathrm{~d}$, for evidence of cell lysis. Wells that did not clear after $10 \mathrm{~d}$ were propagated into fresh exponentially-growing cultures and monitored for another $7 \mathrm{~d}$. Cultures which still did not clear after propagation were scored as negative for the presence of lytic viruses. The number of wells in which lysis occurred, or did not occur, was scored, and the concentration of infective units and the error associated with these estimates were determined using a computer program written in BASIC (Hurley \& Roscoe 1983). We confirmed that viruses were responsible for cell lysis by using TEM to examine representative wells of the microtiter plates containing lysed cells; in every instance lysis was the result of viruses. Estimates obtained for concentrated natural virus communities were converted to ambient abundances assuming that the viruses were concentrated from seawater with $100 \%$ efficiency. Consequently, any loss of viruses due to the concentration procedure would result in titer being underestimated. We have estimated the concentration efficiency of cyanophages infecting several hosts by titering natural seawater before and after concentration by ultrafiltration. Viruses infecting SYN48, SNC2, SNC1, 838BG and DC2 were concentrated with $38.2,60.4,40.2,13.3$ and $26.6 \%$ efficiency, respectively, from an offshore Gulf of Mexico sample. A comparison made using water collected from the MSI pier indicated that viruses infecting SNC2 were concentrated with $58.6 \%$ efficiency.

Epifluorescent microscopy was used to enumerate cyanobacteria in water samples taken along the offshore transect (Waterbury et al. 1986). Seawater subsamples (10 to $25 \mathrm{ml}$ ) were filtered onto $25 \mathrm{~mm}$, $0.2 \mu \mathrm{m}$ pore-size, black polycarbonate filters (Poretics), and the number of yellow (red strains) and red (green strains) autofluorescent cyanobacteria counted in a minimum of 20 microscope fields. Prochlorophytes, which can be difficult to distinguish from redfluorescing cyanobacteria may also have been included in the counts. Ideally, a minimum of 200 cells of each type were counted, although red fluorescing prokaryotic cells were frequently so scarce as to make this impractical.

Isolation and cloning of cyanophages. Seven cyanophages were cloned from natural virus communities S-BBS1 was isolated by plaque purification using
ESAW solidified with $1 \%$ agar; the other viruses were cloned in liquid using a dilution assay (Cottrell \& Suttle 1991). In this procedure, a small aliquot of lysed culture was filtered through a $0.2 \mu \mathrm{m}$-pore-size polycarbonate filter and transferred into an exponentiallygrowing culture of the host. The pathogen was propagated in this manner several times to dilute out non-replicating viruses. The virus was cloned by determining the most probable number (MPN) of infective units (Taylor 1962) and adding 0.2 infective units to each of 20 susceptible host cultures. The cultures in which lysis occurred were assumed to have a single infective virus; the probability that more than 1 infective unit occurred in a given culture is 0.0176 .

Electron microscopy. Viral lysates were filtered $(0.2 \mu \mathrm{m})$ and concentrated by ultracentrifugation $(146000 \times g)$ at $20^{\circ} \mathrm{C}$ in an AH-629 swinging-bucket rotor (Sorvall), for $2.75 \mathrm{~h}$. The pellets were resuspended in about $200 \mu$ l of ESAW. Viruses were transferred to 400 mesh, carbon-coated copper grids by floating the grids on drops of the resuspended virus solutions for ca 20 min. The grids were stained by floating them on a drop of $1 \%$ aqueous uranyl acetate for 20 to $30 \mathrm{~s}$. The excess stain was wicked off with filter paper and the grids were viewed at $80 \mathrm{kV}$ using either a Philips EM301 or a JOEL-100CX transmission electron microscope.

Host range studies. Host specificity of S-BBP1 through S-PWP1 was tested in liquid culture against 8 strains of marine Synechococcus spp. and 1 strain of Anacystis marina. Cyanophages were screened for host specificity using culture lysate from a susceptible cyanobacteria culture to which cloned cyanophage was added. The lysate was $0.2 \mu \mathrm{m}$ filtered and $50 \mu \mathrm{l}$ was added to each of quadruplicate $5 \mathrm{ml}$ exponentially-growing cultures containing a potential host. Controls included cultures to which no virus was added and cultures to which host culture filtrate was added. The effect of the added virus on the potential host was determined by monitoring in vivo chlorophyll fluorescence. Cyanobacteria cultures that had not lysed $4 \mathrm{~d}$ after reaching stationary phase were considered to be unsuitable hosts for the virus. Lysates from strains that were sensitive to the pathogen were $0.2 \mu \mathrm{m}$ filtered and reinoculated into a new culture to ensure that the effect could be propagated.

In addition to being tested against 9 strains of marine cyanobacteria, S-BBS1 was tested against Microcystis aeruginosa and 4 strains of freshwater Synechococcus spp. Most of these host-range studies were done using triplicate plaque assays. Typically, an exponentiallygrowing cyanobacteria culture (ca $10^{7}$ cells $\mathrm{ml}^{-1}$ ) was concentrated about 100 fold by centrifugation (15 min, $10000 \times g, 18^{\circ} \mathrm{C}$ ) and the cells resuspended in marine (ESAW) or freshwater (Allen 1968) growth medium, or 
a combination of the 2 (1:1 ESAW:Allen's), as appropriate. A $500 \mu \mathrm{l}$ aliquot of this cell suspension (ca $5 \times$ $10^{8}$ cells) was combined with $500 \mu$ or less of a solution. of the virus to be tested for host specificity, and the viruses allowed to adsorb for 45 to $60 \mathrm{~min}$. This mixture was added to $2.5 \mathrm{ml}$ of $0.6 \%$ molten $\left(46^{\circ} \mathrm{C}\right)$ purified agar (Sigma) in growth medium, mixed quickly by vortexing and poured directly onto a solidified bottom layer made with $1.0 \%$ purified agar and growth medium. After the top-agar hardened, the plates were inverted and incubated at $25^{\circ} \mathrm{C}$ under continuous illumination at $36 \mu \mathrm{mol}$ quanta $\mathrm{m}^{-2} \mathrm{~s}^{-1}$. Plaques appeared in 3 to $5 \mathrm{~d}$. As a control, S-BBS1 was also assayed against $\mathrm{BBC} 1$ grown on the 3 types of solid media.

For potential hosts of S-BBS1 which did not grow well in top agar, screening was done in liquid media. These included DC2, SYN48 and 838BG, which were tested in ESAW, and Microcystis aeruginosa which was tested in Allen's medium. As a control, S-BDS1 was screened against BBC1 grown in both types of liquid media. Treatments were in triplicate. The $0.2 \mu \mathrm{m}$ filtered (polycarbonate, Poretics) S-BBS1 was added to the exponentially growing potential hosts at a virus to host ratio of about 0.01 . About 3 to $5 \mathrm{~d}$ after the cells reached stationary growth, aliquots of the cultures were plaque assayed against BBC1 to test for amplification of S-BBS1 by the other hosts.

Adsorption kinetics and growth cycle. Standard protocols (Adams 1959) were used to determine the adsorption kinetics for cyanophage S-BBS1 cultured on strain BBC1, growing in ESAW. Approximately $9 \times 10^{6}$ cells $\mathrm{ml}^{-1}$ from an exponentially-growing culture of BBC1 were combined with S-BBS1 at a virus to host ratio of 0.01 . Following mixing, triplicate samples were immediately removed, diluted 10 fold with ice cold ESAW and centrifuged for $5 \mathrm{~min}$ at $5200 \times \mathrm{g}$ at
$5{ }^{\circ} \mathrm{C}$ to remove cells with attached viruses. The supernatant was promptly titered for unabsorbed viruses. Additional samples were assayed for unabsorbed viruses at 15, 30,45 and $60 \mathrm{~min}$. The adsorption rate constant (time $\mathrm{e}^{-1}$ ) was determined by multiplying the slope of a semi-log plot of the percent of free virus remaining in solution versus time by 2.3 . This was divided by the host concentration to express the constant in the traditional units of $\mathrm{ml} \mathrm{min}{ }^{-1}$.

Growth of the virus in the host cell was determined by 1 -step growth experiments (Adams 1959, Van Etten et al. 1983). Triplicate cultures of BBC1 (ca $2.3 \times 10^{7}$ cells $\mathrm{ml}^{-1}$ ) were inoculated with S-BBS1 virus at a virus to host ratio of 0.02 and allowed to adsorb for $60 \mathrm{~min}$ at $25^{\circ} \mathrm{C}$. Each host-virus solution was centrifuged briefly. The pellet was washed once with ESAW, resuspended, and diluted $400 \times$ and $40000 \times$ in ESAW. At predetermined intervals duplicate aliquots were withdrawn and titcred by plaque assay as described above, to determine the total number of infective centers. The infected cultures were incubated at $25^{\circ} \mathrm{C}$ at an irradiance of $36 \mu \mathrm{mol}$ quanta $\mathrm{m}^{-2} \mathrm{~s}^{-1}$.

$\mathrm{CO}_{2}$ fixation. Cyanophage clone S-BBS1 was added to triplicate $60 \mathrm{ml}$ exponentially-growing cultures of Synechococcus $\mathrm{sp}$. strain $\mathrm{BBC} 1$ at a virus to host ratio of about 1 , and $10 \mu \mathrm{Ci}$ of ${ }^{14} \mathrm{C}$-bicarbonate was added. The cultures were incubated under fluorescent lights at an irradiance of $100 \mu \mathrm{mol}$ quanta $\mathrm{m}^{-2} \mathrm{~s}^{-1}$. Rates of isotope incorporation were compared to control cultures to which viruses were not added. At predetermined times, $10 \mathrm{ml}$ samples were filtered onto $0.2 \mu \mathrm{m}$ pore-size, cellulose-nitrate membranes, acid fumed overnight and the radioactivity on the filters determined by liquid scintillation counting. Standard errors of the ratio of uptake rates in the treatment and control cultures were calculated as described in Yates (1981).

Table 1. Occurrence of cyanophages infecting Synechococcus spp.

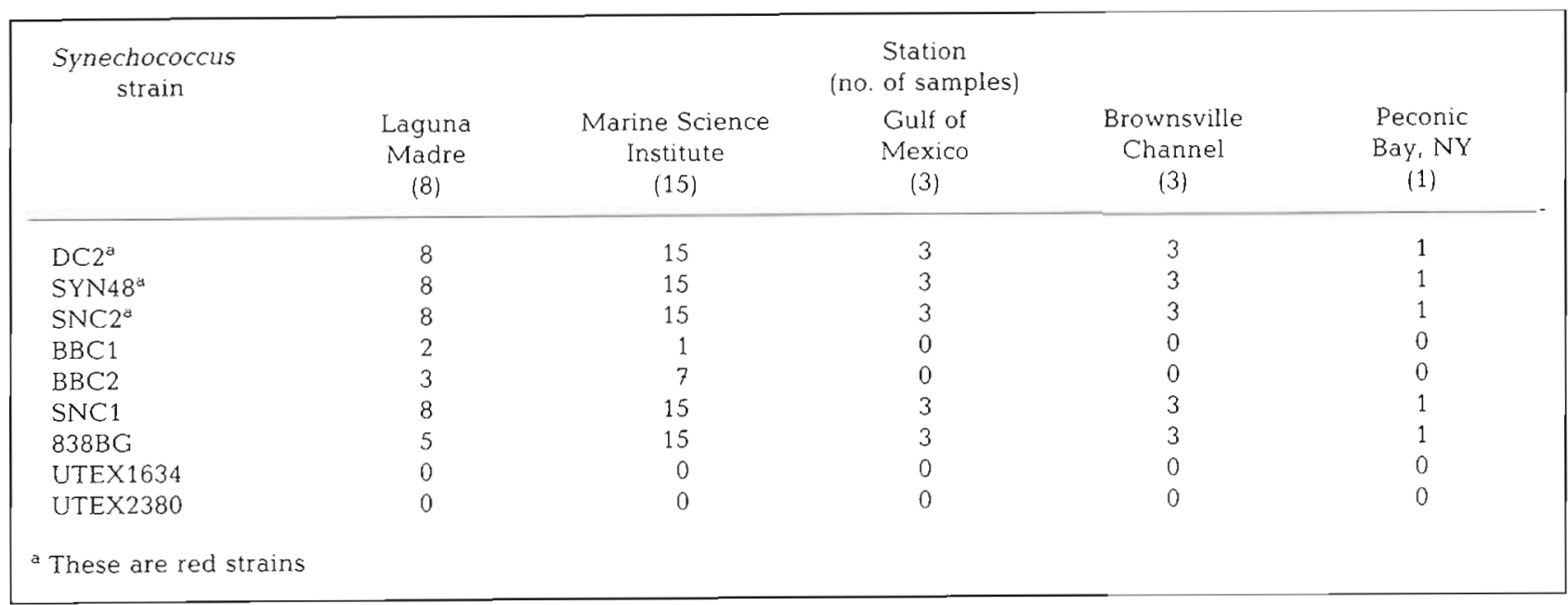




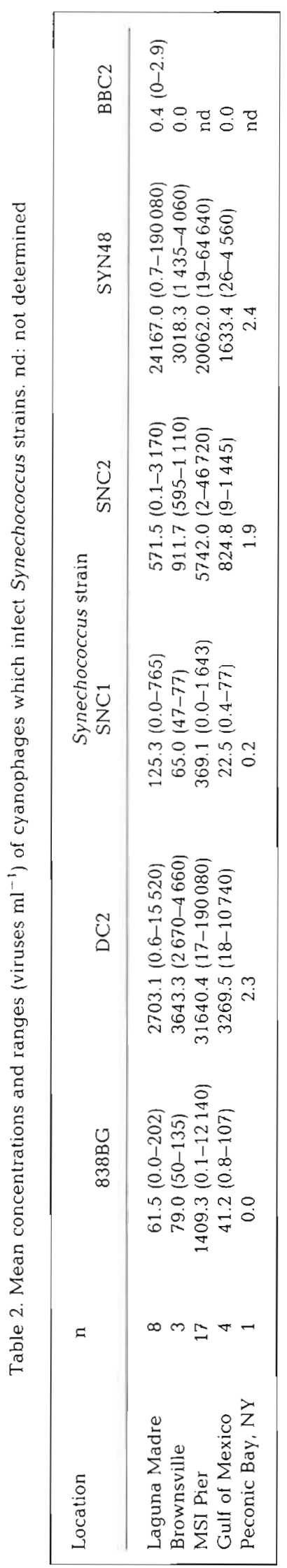

\section{RESULTS AND DISCUSSION}

\section{Cyanophage distribution and abundance}

Viruses that infect Synechococcus spp are widely occurring in the marine environment. We detected lytic cyanophages in every virus community that we screened including communities from a hypersaline lagoon (Laguna Madre), nearshore and neritic waters of the Gulf of Mexico and in a sample from Peconic Bay, New York (Table 1). Cyanophages that caused lysis of the red strains (DC2, SYN48, and SNC2) and some of the green strains ( $\mathrm{SNC1}$ and $838 \mathrm{BG}$ ) were detected in all or almost all of the virus communities, whereas those that infected other green strains were much less common. For example, lytic pathogens of UTEX 1634 and 2380 were not detected. As well, $<10 \%$ and $<30 \%$ of the virus communities contained viruses which caused lysis of $\mathrm{BBC} 1$ and $\mathrm{BBC} 2$, respectively.

The abundance of cyanophages was temporally variable, ranging from undetectable to as high as $1.9 \times$ $10^{5} \mathrm{ml}^{-1}$, and strongly depended on the host that was screened (Table 2). Frequently, concentrations were in excess of $10^{4} \mathrm{ml}^{-1}$ for some hosts. In almost every instance, the viruses infecting the red strains of Synechococcus spp. were present in the highest concentrations. Furthermore, the cyanobacteria for which the highest titers of cyanophages were routinely recorded (DC2 and SYN48) were open ocean isolates from the North Atlantic and tropical Atlantic, respectively. Viruses infecting a red strain from Laguna Madre (SNC2) were also widely occurring, but not as abundant as the oceanic strains. Although the data are limited they suggest that oceanic strains of Synechococcus spp. may be more sensitive to phage infection than coastal strains.

Cyanophages occurred over the entire range of salinities (18 to $70 \mathrm{ppt}$ ) and temperatures (12 to $30.4^{\circ} \mathrm{C}$ ) that we screened; however, the lowest titers were coincident with cooler temperatures during spring 1990 and 1991, as is indicated by the weak correlations between cyanophage abundance and water temperature for samples taken from the Institute pier (Fig. 1; range in $\mathrm{r}^{2}, 0.53$ to 0.70 ). Culture studies with freshwater phytoplankton communities have shown that the contribution of cyanobacteria to total phytoplankton biovolume increases with increasing water temperature (Tilman \& Kiesling 1983). Consequently, Synechococcus spp. abundances were likely greater when water temperatures were warmer and the highest concentrations of cyanophages were recorded.

Along a transect in the western Gulf of Mexico, cyanophage concentrations infecting DC2 and SYN48 were in excess of $10^{4} \mathrm{ml}^{-1}$ (Fig. 2). The highest titers 


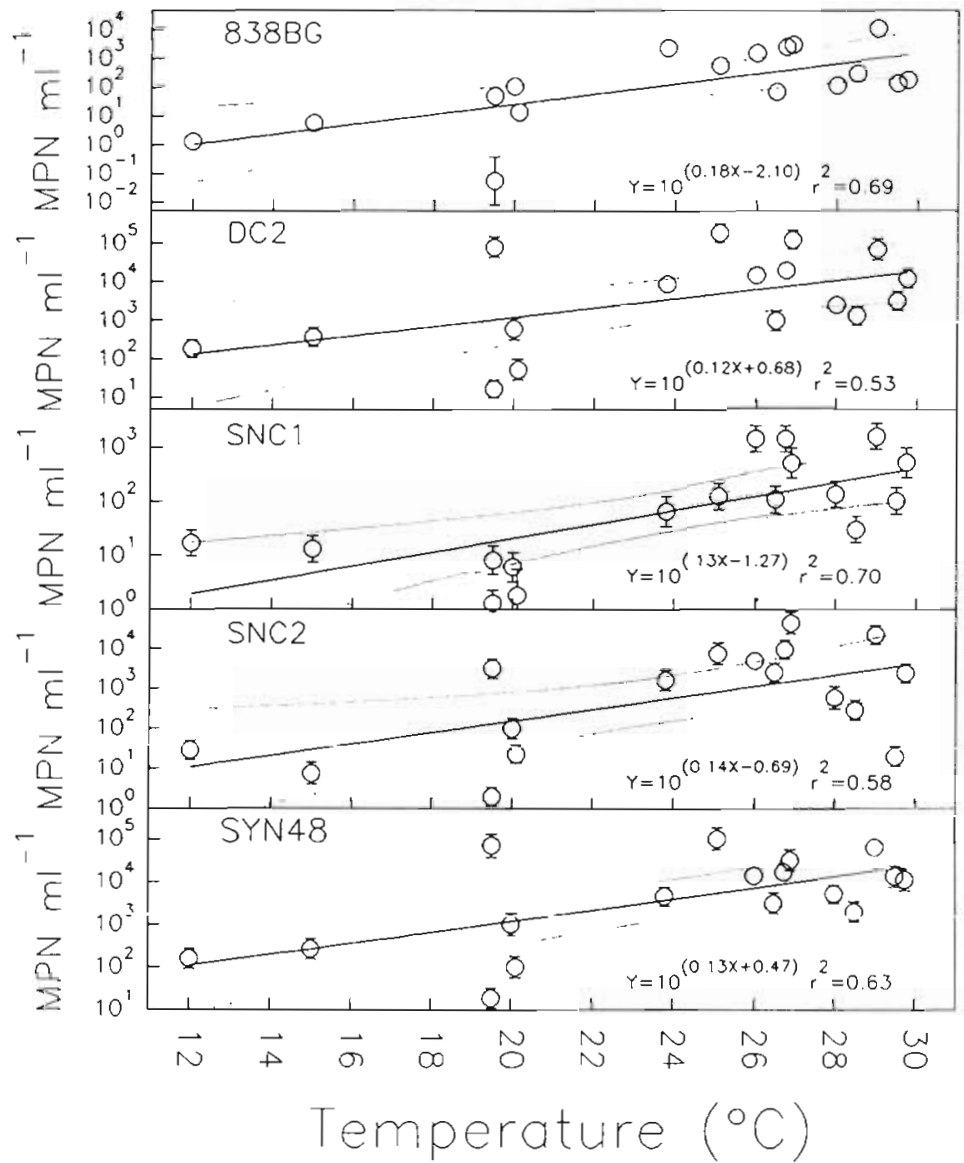

Fig. 1. Synechococcus spp. Relationship between temperature $\left({ }^{\circ} \mathrm{C}\right)$ and the concentration of cyanophages (MPN of viruses $\mathrm{ml}^{-1}$ ) in coastal seawater that infect strains of Synechococcus spp. Water was collected from the MSI pier on 17 dates between 16 March 1990 and 9 June 1992. MPN: most probable number

were associated with the greatest concentrations of yellow-fluorescing Synechococcus spp. cells (red strains) for 4 of the 5 hosts screened, suggesting a coupling between cyanophage and host abundance. As well, cyanophage concentrations occasionally reached $>10^{5} \mathrm{ml}^{-1}$ in inshore samples (Table 2, Fig. 1). Cell and cyanophage concentrations dropped by about half and 10-fold, respectively, as the ship moved between 2 visibly different water types, indicated by a 5 ppt increase in salinity. Viruses infecting SNC1 and SNC2 followed a similar pattern, although they were considerably less abundant. The red-fluorescing cyanobacteria (green strains), which may have included prochlorophytes, were much less abundant and not as obviously tied to changes in water type. Concentrations of viruses that infected 838BG (a green strain originally isolated from the Gulf of Mexico) were similar on both sides of the salinity change, as well. Other recent studies have demonstrated high concentrations of cyanophages in seawater. Waterbury \& Valois (1992) reported cyanophage concentrations of $3.9 \times$ $10^{4}$ in Woods Hole Harbor and $2.1 \times 10^{3}$ in slope water, and Suttle et al. (1993) recorded abundances $>10^{5} \mathrm{ml}^{-1}$ in nearshore regions of the western Gulf of Mexico.

It is significant that viruses in seawater from a hypersaline lagoon, the coastal waters of Texas and New York, and the Gulf of Mexico were able to infect hosts that were isolated from the North and tropical Atlantic, as well as Texas. Obviously, a single isolate of Synechococcus sp. can be infected by viruses that occur in widely separated regions. This was also reported for viruses infecting the eukaryotic photosynthetic flagellate Micromonas pusilla (Cottrell \& Suttle 1991).

\section{Cyanophage morphology}

The 7 cyanophages that we cloned from marine waters had tails and icosahedral heads. They belong to the same 3 families of viruses that have been observed to infect freshwater cyanobacteria, namely the Siphoviridae (formerly Styloviridae), Myoviridae and Podoviridae (see reviews by Padan \& Shilo 1973, Stewart \& Daft 1977, Safferman et al. 1983, Ackermann \& DuBow 1987, Martin $\&$ Benson 1988). Safferman et al. (1983) have suggested that these families be further classified into 3 genera: Cyanostylovirus spp., Cyanomyovirus spp. and Cyanopodovirus spp. S-BBS1 (Fig. 3a) is ca $290 \mathrm{~nm}$ in overall length and has the long, flexible, noncontractile tail (ca $230 \mathrm{~nm}$ ) characteristic of Cyanostylovirus spp., although the tail is considerably longer than has been reported for freshwater isolates (e.g. Fox et al. 1976). The very short tails suggest that S-BBP1 and SPWP1 (Fig. 3b, c) are Cyanopodovirus spp., although it appears that S-PWP1 possesses a contractile sheath. Both S-BBP1 and S-BBS1 have relatively small capsids of similar diameter (ca $50 \mathrm{~nm}$ ); whereas, the capsid of S-PWP1 is somewhat larger (ca $65 \mathrm{~nm}$ ). The cyanophages that we most frequently isolated (S-PWM1, S-PWM2, S-PWM3, S-PWM4) had the relatively long contractile talls associated with Cyanomyovirus spp. (Fig. 3d to g). There was considerable structural variation within this group suggesting that there may be several species of cyanophages within this genus. Of particular interest is the obvious neck filaments found on S-PWM4. Neck filaments have been reported for a number of viruses which infect freshwater filamentous cyanobacteria (e.g. Adolph \& Haselkorn 1973, Padan \& Shilo 1973), but not unicellular forms. As such struc- 


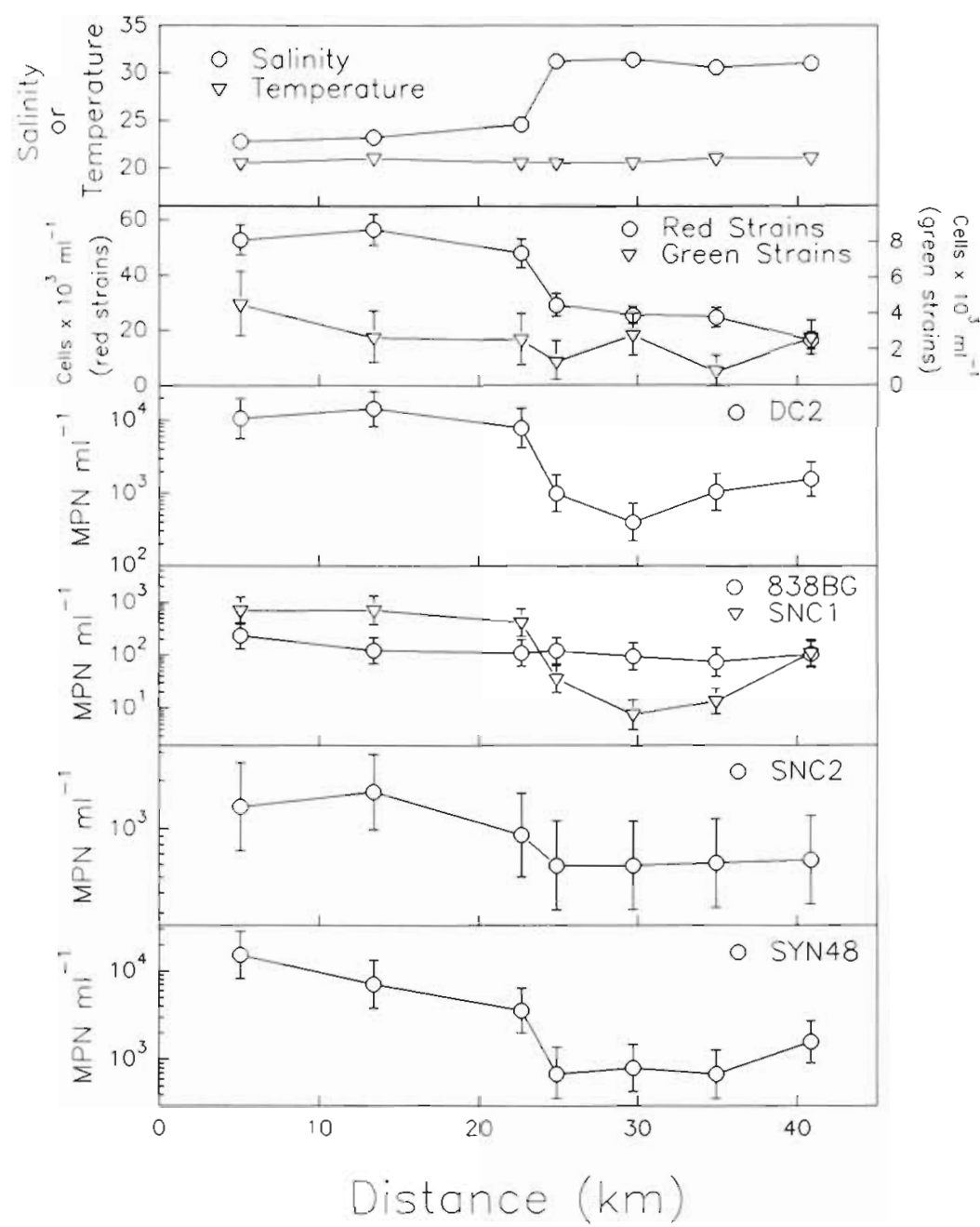

Fig. 2. Synechococcus spp. Salinity (ppt), temperature $\left({ }^{\circ} \mathrm{C}\right.$ ) and concentrations of cyanophages (MPN of viruses $\mathrm{ml}^{-1}$ ) infecting 5 strains of marine Synechococcus spp. isolates along a transect in the western Gulf of Mexico. The abundances of red (yellow-fluorescing) and green (red-fluorescing) strains of unicellular cyanobacteria are also given. MPN: most probable number

tures are extremely rare (Ackermann \& DuBow 1987), it suggests that these freshwater and marine cyanophages may share a common ancestry.

\section{Host range}

As the detection of cyanophages in natural virus communities depended upon the strain of Synechococcus spp. that was screened, it indicated that all cyanophages could not infect all strains of Synechococcus spp. In order to determine the host specificities of the cyanophages, we tested each of the viruses against 8 strains of Synechococcus spp. and 1 strain of Anacystis marina isolated from seawater. The isolates included coastal and oceanic strains, and strains with phycoerythrin or phycocyanin as their dominant pigment. As might be expected the 2 cyanobacterial strains for which the highest titer of infectious viruses was routinely recorded (DC2 and SYN48) were also the isolates which were infected by more than a single virus clone (Table 3 ). The pattern was complicated by the fact that the host range of the phages overlapped. For example, S-PWM3 infected 4 and S-PWM4 infected 2 of the 9 cyanobacterial strains screened, while the 5 other virus clones only infected a single strain of cyanobacteria. Furthermore, S-PWM3 infected a green Synechococcus sp. strain and 3 of the red strains. Evidently, cyanophage and host taxonomy are not closely coupled. In contrast, viral taxonomy may influence the hosts which can be infected. Viruses from all 3 families infected green strains of Synechococcus spp., but all of the virus clones infecting the red strains belonged to the Myoviridae. As well, the stylovirus (S-BBS1) and the podoviruses (S-BBP1 and S-PWP1) each infected a single Synechococcus sp. strain, suggesting that viruses from these families may be more host specific than those from the Myoviridae.

Host range was not obviously tied to location from which the hosts and viruses were isolated. Although the virus clones originated from the coastal waters of Texas, they infected strains of Synechococcus spp. originating from the North and tropical Atlantic (DC2 and SYN48), Gulf of Mexico (838BG, data not shown), coastal waters of Texas (BBC1 and BBC2) and Laguna Madre (SNC1 and SNC2). For example, S-PWM3 infected coastal and oceanic cyanobacterial strains. Similarly, the pigment composition of the host was not tied to infection by a particular viral family, at least for the green strains, which were infected by the 3 virus families. However, the 4 viruses that we cloned which infected the red strains appeared to belong to the same virus family (Myoviridae); whereas, the Syphoviridae and Podoviridae only infected green strains.

Other studies have also revealed that host range among cyanophages is complex. For example, cyanophage SM-1 (Safferman et al. 1969) infected 2 strains of chroococcoid cyanobacteria but not 6 other strains tested; whereas, AS-1 (Safferman et al. 1972) infected 


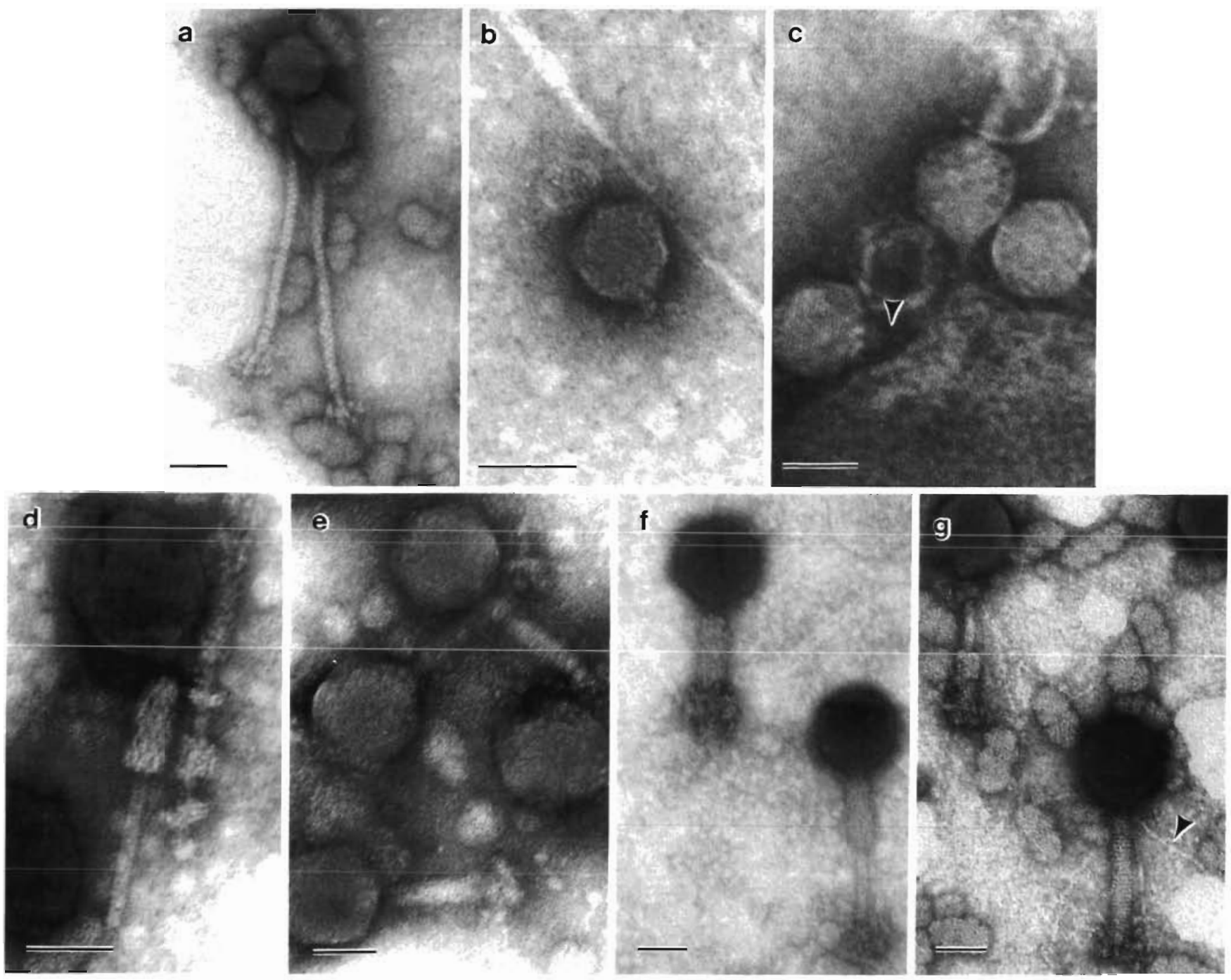

Fig. 3. Electron micrographs of cyanophages infecting marine strains of Synechococcus spp. (a) S-BBS1, Syphoviridae. (b) S-BBP1, Podoviridae. (c) S-PWP1, Podoviridae. (d) S-PWM1, Myoviridae. (e) S-PWM2, Myoviridae. (f) S-PWM3, Myoviridae. (g) S-PWM4, Myoviridae. Scale bars $=50 \mathrm{~nm}$. Arrows indicate an apparent contracted sheath with exposed core in S-PWP1 (c) and neck filaments in S-PWM4 (g)

3 strains of 8 tested. There was no overlap in the host range of these cyanophages. Nonetheless, the relatively high host specificity of the marine cyanophages suggests that the probability of a cyanophage encountering a suitable host is likely small, which may be the reason why high densities of cyanobacteria and cyanophages co-occur in seawater.

Given the morphological similarities among cyanophages isolated from marine and fresh waters it seemed plausible that the marine isolates might also infect freshwater cyanobacteria. As green strains of Synechococcus spp. are commonly observed in lakes, and as Syphoviridae have been isolated which infect a number of freshwater Synechococcus spp. strains, we chose S-BBS1 for more detailed cross-infectivity experiments. S-BBS1 was not able to infect any of 4 freshwater strains of Synechococcus spp. or 1 strain of Microcystis aeruginosa. This was despite the fact that lytic viral pathogens had been previously isolated for 3 of the 4 Synechococcus spp. and for the $M$. aeruginosa strain. These results suggest that marine cyanophages may not readily infect freshwater cyanobacteria.

The effect of viruses on Synechococcus spp. in nature will be difficult to ascertain. Although the number of cyanophages which infect a particular strain of Synechococcus sp. can be quantified, the variation within Synechococcus spp. in terms of phage resistance, and the diversity in host range of cyanophages indicates that the results would only be applicable to a 
Table 3. Synechococcus spp. Host-range of cyanophage clones

\begin{tabular}{|c|c|c|c|c|c|c|c|}
\hline $\begin{array}{c}\text { Synechococcus } \\
\text { strain }\end{array}$ & S-BBS1 & S-BBP1 & S-PWM1 & $\begin{array}{c}\text { Cyanophage clone } \\
\text { S-PWM2 }\end{array}$ & S-PWM3 & S-PWM4 & S.PWP1 \\
\hline $\mathrm{DC} 2^{\mathrm{a}}$ & - & - & + & + & + & + & - \\
\hline SYN48 $8^{\mathrm{a}}$ & - & - & - & - & + & + & - \\
\hline $\mathrm{SNC} 2^{\mathrm{a}}$ & & - & - & - & + & - & - \\
\hline $\mathrm{BBC} 1$ & + & - & - & - & - & - & - \\
\hline $\mathrm{BBC} 2$ & - & + & - & - & - & - & - \\
\hline SNC1 & - & - & - & - & + & - & + \\
\hline $838 \mathrm{BG}$ & - & - & - & - & - & - & - \\
\hline UTEX1634 & - & - & - & - & - & - & - \\
\hline UTEX2380 & - & - & - & - & - & - & - \\
\hline
\end{tabular}

subset of the Synechococcus community. Nonetheless, as rapid viral propagation occurs at high host densities (Wiggins \& Alexander 1985), and lysogeny of Synechococcus spp. appears to be rare (Martin \& Benson 1988), there must be strong selection for the Synechococcus community to remain diverse in terms of viral resistance. Consequently, infection may be an underlying mechanism maintaining high genetic diversity in Synechococcus spp. (Wood \& Townsend 1990).

\section{Adsorption kinetics, photosynthetic rates and the viral growth cycle}

The adsorption of S-BBS1 to BBC1 did not deviate substantially from a $\log$-linear relationship $\left(\mathrm{r}^{2}=0.94\right)$ for the 60 min over which the kinetics were determined (Fig. 4). The average percentage of free viruses

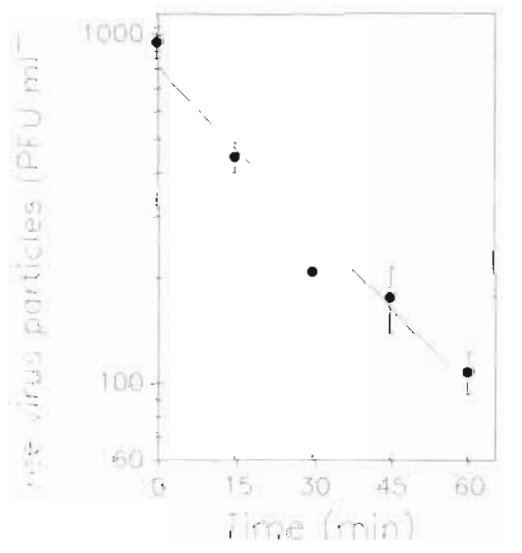

Fig. 4. Adsorption kinetics of cyanophage S-BBS1 on host Synechococcus sp. strain BBC1. Error bars represent the standard deviation from triplicate plaque assays. Where error bars are not shown the standard deviation was less than the width of the symbol remaining at $15,30,45$ and 60 min post-addition were $46.9,22.0,18.5$ and $11.3 \%$, respectively. The average adsorption rate constant over the 60 min incubation. was $0.035 \mathrm{~min}^{-1}\left(3.94 \times 10^{-9} \mathrm{ml} \mathrm{min}^{-1}\right)$, which is slow relative to those typically observed for bacteriophages, but within the range reported for phages adsorbing to freshwater unicellular cyanobacteria (Samimi \& Drews 1978, Cseke \& Farkas 1979, Amla 1981). Rate constants should be useful for determining if theoretical estimates of the probability of virus and host encounter can be used to estimate actual rates of virus adsorption to the surface of cyanophages.

Data from the 1-step growth experiment indicated that onset of cell lysis began about $9 \mathrm{~h}$ following infection and was complete by $17 \mathrm{~h}$ post infection (Fig. 5). Approximately 250 progeny viruses were produced per infected host cell when lysis occurred. This is simi-

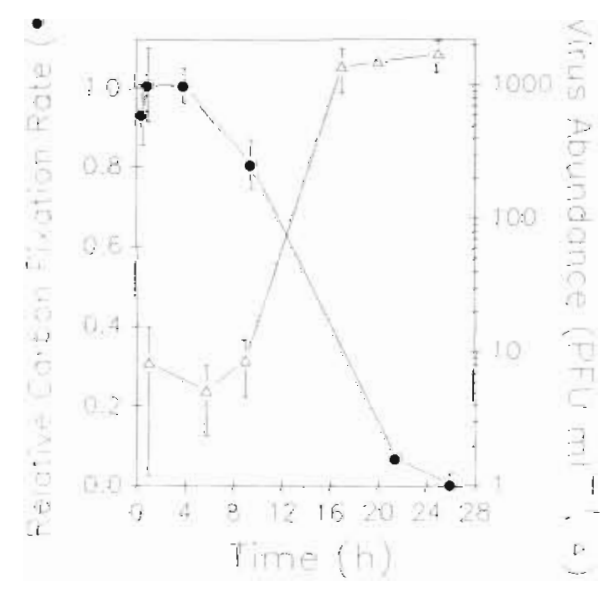

Fig. 5. One-step growth curve of S-BBS1 on Synechococcus $\mathrm{sp}$. host $\mathrm{BBC1}$ and relative photosynthetic rates (experimentals/controls) in cultures of Synechococcus sp. (BBC1) to which a cyanophage (S-BBS1) has been added. Error bars represent the standard deviation (PFU data) or standard error (photosynthesis data) of results from triplicate cultures 
lar to the burst size reported for a Cyanostylovirus $\mathrm{sp}$ that infects freshwater unicellular cyanobacteria (Martin et al. 1978), but is considerably greater than that reported for Cyanomyovirus spp. (Safferman et al. 1972, Sherman \& Connelly 1976).

Photosynthetic rates in infected cultures of BBC1 were similar to those in non-infected controls until near the onset of cell lysis (Fig. 5). At 21 h after infection photosynthetic rates in the infected cultures were $<4 \%$ of those in the controls and by $26 \mathrm{~h}$ inorganic carbon uptake was not detectable in the cultures to which viruses were added. A similar pattern of photosynthetic suppression is observed when freshwater Synechococcus spp. strains are infected by viruses (Mackenzie \& Haselkorn 1972). Photosynthesis continues up until the point of cell lysis. This is in contrast to viruses which infect filamentous freshwater cyanobacteria, where photosynthesis is suppressed shortly after infection and the viral life cycle can continue to completion in the absence of light (Padan et al. 1973).

\section{Implications}

This study in conjunction with others (Proctor \& Fuhrman 1990, Suttle et al. 1990, 1993, Chan \& Suttle 1992. Waterbury \& Valois 1992) demonstrates that infective cyanophages are widespread and likely have considerable impact on natural marine cyanobacteria communities. The high abundances of Synechococcus spp. in the sea and the apparently ubiquitous occurrence of viruses which infect them is somewhat enigmatic. It suggests that most Synechococcus spp. cells are entirely resistant to viral infection or that there is great diversity within the genus in terms of resistance to infection. In either case the implication is that viruses are a major factor structuring the marine cyanobacterial community. Nonetheless, it will be difficult to ascertain the impact of viruses on the population dynamics of Synechococcus spp. because of the diversity of the cyanophages in terms of host-range and of the cyanobacteria in terms of resistance.

Synechococcus is one of the most abundant photosynthetic cells in oligotrophic oceanic environments where it can be responsible for a significant amount of the total primary productivity (e.g. Joint \& Pomroy 1983, Li et al. 1983, Waterbury et al. 1986). If cyanophages lyse a sizable portion of open ocean Synechococcus communities it implies that a substantial proportion of the primary productivity will be lost as dissolved organic matter, viral particles and cellular debris. Ultimately, bacterial processes will recover some of these resources, but overall less nutrients and energy will be shunted from the primary producers to consumers, resulting in an overall decrease in the effi- ciency of nutrient and energy transfer to higher trophic levels.

Acknowledgements. The authors are grateful for the assistance of R. Garza, K. Rodda and M. Kelly in these studies. Dr Dean Stockwell kindly provided water for us from Laguna Madre. This research was funded by grants from the Office of Naval Research (N00014-90-J-1280) and National Science Foundation (OCE-9018833). Contribution number 843 of the Marine Science Institute of The University of Texas at Austin.

\section{LITERATURE CITED}

Ackermann, H.-W., DuBow, M. S. (1987). Viruses of prokaryotes. CRC Press, Boca Raton

Adams, M. K. (1959). Bacteriophages. Interscience Publ., New York

Adolph, K. W., Haselkorn, R. (1973). Blue-green algal virus $\mathrm{N}$-1: physical properties and disassembly into structural parts. Virology 53: 427-440

Allen, M. M (1968). Simple conditions for the growth of unicellular blue-green algae on plates. J. Phycol. 4: 1-4

Amla, D. V. (1981). Isolation and characteristics of a minute plaque forming mutant of cyanophage AS-1. Biochem Physiol. Pflanzen. 176: 83-89

Rrumn, S. F. Taker. R. D.. Sharma, G. M. (1980). Dynamics of phytoplankton productivity in the Peconic Bay estuary. Estuar. coast. Shelf Sci. 10: 247-263

Carpenter, E. J., Romans, K. (1991). Major role of the cyanobacterium Trichodesmium in nutrient cycling in the North Atlantic Ocean. Science 254: 1356-1358

Chan, A. M., Suttle, C. A. (1992). Host specificity, occurrence, and morphology of cyanophages infecting marine Synechococcus. In: Abstr. Aquatic Sciences Meeting, Santa Fe, NM, 9-14 Feb 1992. Am. Soc. Limnol. Oceanogr., Lawrence, KS

Cottrell, M. T., Suttle, C. A. (1991). Wide-spread occurrence and clonal variation in viruses which cause lysis of a cosmopolitan, eukaryotic marine phytoplankter, Micromonas pusilla. Mar. Ecol. Prog. Ser. 78: 1-9

Cseke, C. S., Farkas, G. L. (1979). Effect of light on the attachment of cyanophage AS-1 to Anacystis nidulans. J. Bacteriol. 137: 667-669

Fox, J. A., Booth, S. J., Martin, E. L. (1976). Cyanophage SM2: a new blue-green algal virus. Virology 73: 557-560.

Harrison, P. J., Waters, R., Taylor, F. J. (1980). A broad spectrum artificial seawater medium for coastal and open ocean phytoplankton. J. Phycol. 16: 28-35

Hurley, M. A., Roscoe, M. E. (1983). Automated statistical analysis of microbial enumeration by dilution series. $\mathrm{J}$ appl. Bacteriol. 55: 159-164.

Joint, I. R., Pomroy, A. J (1983). Production of picoplankton and small nanoplankton in the Celtic Sea. Mar. Biol. 77: $19-27$

Li, W. K. W., Subba Rao, D. V., Harrison, W. G., Smith, J. C. Cullen, J. J., Irwin, B., Platt, T (1983). Autotrophic picoplankton in the tropical ocean. Science 219: 292-295

Mackenzie, J. J., Haselkorn, R. (1972). Photosynthesis and the development of blue-green algal virus SM-1 Virology 49 . 517-521

Mãrtin, E., Benson, R. (1988). Phages of cyanobacteria. In: Calendar, R. (ed.) The bacteriophages, Vol. 2. Plenum Publ., New York, p. 607-645

Martin, E. L., Leach, J. E., Kuo, K. J. (1978). Biological regulation of bloom-causing blue-green algae. In: Louitat, M. W. 
Miles, J. A. R. (eds.) Microbial ecology. Springer Verlag, Berlin, p. 62-67

Murphy, L. S., Haugen, E. M.. (1985). The distribution and abundance of picoplankton in the North Atlantic. Limnol. Oceanogr. 30: 47-58

Padan, E., Ginzburg, D. Shilo, M. (1973). The reproductive cycle of cyanophage LPP1-G in Plectonema boryanum and its dependence on photosynthetic and respiratory systems. Virology 40: 514-521

Padan, E., Shilo, M. (1973). Cyanophages - viruses attacking blue-green algae. Bacteriol. Rev. 37: 343-370

Proctor, L. M., Fuhrmān, J. A. (1990). Viral mortality of marine bacteria and cyanobacteria. Nature 343: 60-62

Safferman, R. S., Cannon, R. E., Desjardins, P. R. Gromov, B. V., Haselkorn, R., Sherman, L. A., Shilo, M. (1983). Classification and nomenclature of viruses of cyanobacteria. Intervirology 19:61-66.

Safferman, R. S., Diener, T. O., Desjardins, P. R., Morris, M. E. (1972). Isolation and characterization of AS-1, a phycovirus infecting the blue-green algae, Anacystis nidulans and Synechococcus cedorum. Virology 47: 105-113

Safferman, R. S., Morris, M. E. (1967). Observations on the occurrence, distribution and seasonal incidence of blue-green algal viruses. Appl. Microbiol. 15: 1219-1222

Safferman, R. S., Schneider, I. R., Steere, R. L., Morris, M. E., Diener, T O. (1969). Phycovirus SM-1: a virus infecting unicellular blue-green algae. Virology 37: 386-395

Samimi, B., Drews, G. (1978). Adsorption of cyanophage AS-1 to unicellular cyanobacteria and isolation of receptor material from Anacystis nidulans. J. Virol. 25: $164-174$

Sherman, L. A., Connelley, M. (1976). Isolation and characterization of a cyanophage infecting the unicellular bluegreen algae $A$. nidulans and $S$. cedorum. Virology 72 : $540-544$

Stewart, W. D. P., Daft, M. J. (1977). Microbial pathogens of cyanophycean blooms. In: Droop, M. R., Jannasch, H. W. (eds.) Advances in aquatic microbiology. Academic Press, London, p. $177-218$

This article was submitted to the editor
Suttle, C. A., Chan, A. M., Chen, F., Garza, D.R. (1993). Cyanophages and sunlight: a paradox. Proc. int. Symp. Microbial Ecol., Barcelona, 1992. in press

Suttle, C. A., Chan, A. M., Cottrell, M. T (1990). Infection of phytoplankton by viruses and reduction of primary productivity. Nature 347:467-469

Suttle, C. A., Chan, A. M., Cottrell, M. T (1991). Use of ultrafiltration to isolate viruses from seawater which are pathogens of marine phytoplankton. Appl. environ. Microbiol. 57: $721-726$

Taylor, $J$ (1962). The estimation of numbers of bacteria by tenfold dilution series. J. appl. Bact. 25: 54-61

Tilman, D., Kiesling, R. L. (1983). Freshwater algal ecology: taxonomic trade-offs in the temperature dependence of nutrient competitive abilities. In: Droop, M. R., Jannasch, H. W. (eds.) Current perspectives in microbial ecology. Academic Press, London, p. 314-319

Van Etten, J. L., Burbank, D. E., Xia, Y., Meints, R. H. (1983). Growth cycle of a virus, PBCV-1, that infects Chlorellalike aigae. Virology 126: 117-125

Waterbury, J. B., Valois, F. W. (1992). Cyanophages of marine Synechococcus. In: Abstr. Aquatic Sciences Meeting, Santa Fe, NM, 9-14 Feb 1992. Am. Soc. Limnol. Oceanogr., Lawrence, KS

Waterbury, J. B., Watson, S. W., Valois, F. W., Franks, D. G. (1986). Biological and ecological characterization of the marine unicellular cyanobacterium Synechococcus. In: Platt, T., Li, W. K. W. (eds.) Photosynthetic picoplankton. Can. Bull. Fish Aquat. Sci. 214: 71-120

Wiggins, B. A., Alexander, M. (1985). Minimum bacterial density for bacteriophage replication: implications for significance of bacteriophages in natural ecosystems. Appl. environ. Microbiol 49: 19-23

Wood, A. M., Townsend, D. (1990). DNA polymorphism within the WH7803 serogroup of marine Synechococcus spp. (Cyanobacteria). J. Phycol. 26: 576-585

Yates, F. (1981). Sampling methods for censuses and surveys, 4 th edn. MacMillan, New York

Manuscript first received: September 7, 1992

Revised version accepted: December 4, 1992 